\title{
Orman Yangınlarının Kuzugöbeği Mantarının (Morchella spp.) Çoğalması Üzerine Etkilerinin Araştırılması: Giresun, Alucra Örneği
}

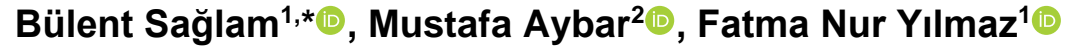 \\ ${ }^{1}$ Artvin Çoruh Üniversitesi, Orman Fakültesi, Orman Mühendisliği Bölümü, 08000, Artvin. \\ ${ }^{2}$ Artvin Çoruh Üniversitesi, Meslek Yüksekokulu, Ormancılık ve Orman Ürünleri Programı, 08000, Artvin.
}

\section{Özet}

Türkiye'de her yll binlerce hektar alanda etkili olan orman yangınlarından sonra yanan alanlarda birçok yeni bitki ve hayvan türü ortaya çıkmaktadır. Aynı şekilde yangınlardan sonra bölgede çok sayıda mantar türünün yoğun olarak ortaya çıktı̆̆ bilinmektedir. Bu türlerden kuzugöbeği mantarı (Morchella spp.) fiyatı çok yüksek olmasına rağmen tüm dünyada sevilerek tüketilmektedir. Mantar toplayarak gelir temin eden yöre halkı nazarında kuzugöbeği mantarı potansiyel yüksek bir gelir kaynağıdır. Kuzugöbeği mantarlarının bazı türleri, orman yangınlarından sonra yanmış alanlarda toprak kimyasındaki ani değişiklikler, küçük dal ve yaprakların yanması sonucu oluşan kül birikmesi nedeniyle bol miktarda ortaya çıkar. Bu çalışmanın amacı, yanan ormanlık alanlarda toprak reaksiyonu $(\mathrm{pH})$ ve organik maddeye bağlı olarak kuzugöbeği mantarının çoğalma potansiyelini belirlemektir. Sonuçlar, yangınla birlikte toprak pH'ının ve beraberindeki organik maddenin arttığını ve dolayısıyla kuzugöbeği mantarı çoğalmasının arttığını göstermiştir. Mantar, toprak pH değeri yüksek ve organik madde oranı düşük veya organik maddesi yüksek ve toprak $\mathrm{pH}$ değeri düşük topraklarda tek başına tespit edilmemiştir. Alanda yüksek toprak pH'sı ve yüksek organik madde birlikte bulunmalıdır. Orman yangınına maruz kalan ve mantarın bulunduğu alanların ortalama organik madde ve pH değerleri sirasiyla 7,25 ve 6,71 olarak bulunurken, aynı ekolojik özellikleri gösteren yanmamış orman alanının ortalama organik madde ve pH değerleri sırasıyla 5,65 ve 5.98 olarak bulunmuştur. Ülkemiz ormanlarında tahribata neden olan en önemli doğal afetlerden biri olan orman yangınlarının kuzugöbeği mantarı üretimi kapsamında da kullanılabileceği söylenebilir. Yanan alanlardaki mantar üretiminden elde edilen gelir, yerel orman köylülerinin gelirlerini artıracak ve sınırlı yıllık bütçelerine ek bir mali yardım sağlayacaktır.

Anahtar Sözcükler

Morchella, Orman Yangını, Kuzugöbeği Mantarı, Orman Köylüsü

\section{Investigation of Forest Fire Effects on Morel (Morchella spp.) Mushroom Proliferation: A Case Study of Alucra, Giresun}

\begin{abstract}
After each forest fire, which are effective in thousands of hectares of land every year in Turkey, many new plant species appear in burning areas and many animals start browsing on these areas. Likewise, it is known that many mushroom species intensely emerge in the area after each fire. Among these species, some species of Morel mushrooms (Morchella spp.), which are consumed all around the world despite their high price. For that reason, it is a very high potential income source for the local forest villagers. Some kinds of Morel mushroom species emerge abundantly in burnt areas after forest fires due to sudden changes in soil chemistry and ash accumulation after the burns of small branches and lives. The aim of this present study is to determine Morel mushroom proliferation growth potential after burnt of forested land based on the soil $\mathrm{pH}$ and organic matter. Our results showed that together with the fire, the soil pH and accompanying organic matter increased and therefore proliferation of the morel mushroom increased. The soils that the mushroom was not detected on have either high $\mathrm{pH}$ value and low organic matter or high organic matter and low soil $\mathrm{pH}$ value alone. A high soil $\mathrm{pH}$ and high organic matter should be presented at the site together. The average organic matter and $\mathrm{pH}$ values of the area which including mushroom exposed to forest fire were found to be 7.25 and 6.71 respectively while the average organic matter and $\mathrm{pH}$ values of the unburned forested area showing same ecological characteristics were found to be 5.65 and 5.98. We conclude that forest fires, one of the most important natural disasters that cause damage in the forests, can also be used within the scope of morel mushroom production. Income from mushroom production in the burnt areas will boost the income of local forest villagers and make an additional financial relief into their limited annual budgets.
\end{abstract}

\section{$\underline{\text { Keywords }}$}

Morchella, Forest Fire, Morel Mushroom, Forest Villagers

\footnotetext{
* Sorumlu Yazar: Tel: +90 (466) 2151035 Faks: +90 (466) 2151034

E-posta: bsaglam@artvin.edu.tr (Sağlam B), mustafaaybar@artvin.edu.tr (Aybar M), fatmanuryilmaz@artvin.edu.tr (Yılmaz FN)
}

Gönderim Tarihi / Received : 17/07/2020 


\section{Giriş}

Orman yangınları dünyanın yangına hassas birçok ülkesinde olduğu gibi ülkemizde de orman alanlarında etkili olan ve her yıl ortalama 8 bin hektar orman alanının zarar görmesine ve zaman zaman önemli oranda can ve mal kayıplarının da yaşanmasına sebep olan doğal bir afettir. Ülkemizin sahip olduğu 22.7 milyon hektarlık ormanlık alanların yaklaşık \% 58 'i yangınlara 1. ve 2. derecede hassas alanlardan oluşmaktadır (URL-1 2019). Dolayısıyla, orman yangınları ülkemiz açısından birlikte yaşamayı öğrenmek zorunda olduğumuz doğal afetlerdendir. Her ne kadar her yıl orman yangınlarının çıkmasına engel olmak ve/veya çıkan orman yangınlarının en az hasarla söndürülmesini sağlamak üzere Orman Genel Müdürlüğü (OGM) tarafından kapsamlı ve etkili çalışmalar yapılıyor olsa da dünyanın hiçbir yerinde yangınların tamamen ortadan kaldırılması veya çıkmasına engel olunması mümkün olamamaktadır. Bu nedenle, yangınların adet ve alan olarak mücadele ve kontrol edilebilir oranlarda kalmasını sağlamak son derece önemlidir.

Orman yangınları, yanan orman alanlarının yapısına bağlı olarak çok büyük enerjinin ve yüksek sıcaklıkların ortaya çıktığı afetlerdir. Bu nedenle, yangın sonrası yanan alanda çoğunlukla büyük zararlar ve bazen de çok farklı değişimler ortaya çıkmaktadır. Bunun temel nedeni, orman yanıcı maddelerini oluşturan otsu ve odunsu vejetasyonun yanmaya son derece elverişli olmalarıdır. Yanıcı madde, topoğrafya ve hava hallerine bağlı olarak oluşan şiddetli yangınlardan sonra çoğunlukla vejetasyonun tamamı zarar görüp alandan uzaklaşmakta iken, düşük şiddetli yangınlarda ise vejetasyonun yapı ve düzenine bağlı olarak alanda farklı bir gelişim gözlenebilmektedir (Alcañiz vd. 2018; Úbeda vd. 2018). Bazı türler alandan uzaklaşırken, yeni bazı türlerin alana gelebildiği görülmektedir. Yangından sonra alana türlerin gelebilmesine sebep olan mekanizmalar, türlerin yaşamsal fonksiyonlarıyla doğrudan ilişkilidir. Bir başka ifadeyle bazı türlerin istediği şartların yangın sonrasında oluşmasıyla alana gelebildikleri görülmektedir (Greene vd. 2007). Bu konuda, özellikle yangın sonrasında mineral toprağı örten diri ve ölü örtü tabakasının yanarak ortadan kalkması ile mineral toprağın açığa çıkması, yanan bitki kısımlarından oluşan külün yüksek oranda besin elementi içermesi ve toprak pH'sında meydana gelen değişiklikler belirleyici olmaktadır (Eron ve Gürbüzer 1988). Yangın sonrasında alana gelen türler içerisinde, bazı mantar türleri de önemli bir yer tutmaktadır (Miller vd. 1994). Yapılan incelemelerde (Pilz vd. 2004), özellikle kuzugöbeği mantarının bazı türlerinin yanan alanlarda yoğun bir şekilde ortaya çıktığı gözlenmiştir. Bu nedenle, mantarlar arasında çok tercih edilip tüketilen, ekonomik değeri oldukça yüksek olan kuzugöbeği mantarı ile orman yangınları arasındaki ilişkinin araştırılması ihtiyaç olmuştur. Bu çalışmada, orman yangınlarının kuzugöbeği mantarı oluşumuna nasıl yardımcı olduğu veya etki ettiğini genel olarak değerlendirmek ve bundan sonra yapılacak çalışmalara bir altlık oluşturmak amaçlanmıştır.

Morchellaceae familyası içerisinde yer alan kuzugöbeği mantarı (Morchella spp.) hassas tatları ve eşsiz görünümü nedeniyle dünya ticaretinde önemli yeri olan bir mantar türüdür (Carluccio 1995). Kuzugöbeği mantarı, tüm mantarlar gibi özellikle protein açısından oldukça zengin içeriğe sahiptir (Tablo 1). Kurutulmuş hali \%42 oranında proteine sahip olan kuzugöbeği mantarı oldukça besleyici, düşük kalorili ve minerallerce zengindir. Fakat sadece besleyiciliği için değil aynı zamanda tadı için de bu mantarın tüketildiği belirtilmiştir (Iqbal 1993). Bu mantarın içerdiği heteroglikan polisakkaritinin, antihiperglisemik ve antitümör etki gösterdiği düşünülmektedir (Liu vd. 2018). Ayrıca yine bu mantardan izole edilen galaktomannanın makrofajların aktivasyonunu uyardığı belirtilmiştir (Duncan vd. 2002). Yapılmış pek çok çalışma ile antimikrobiyal (Kalyoncu vd. 2010), antioksidan (Anguiano vd. 2007) ve nefroprotektif (Nitha ve Janardhanan 2008) etkiler gösterdiği raporlanmıştır.

Kuzugöbeği mantarı, diğer birçok mantar türünden farklıdır. Hasat edilen diğer orman mantarlarıyla karşılaştırıldığında, daha geniş bir ekosistemde yayılış göstermekte; genetik olarak çeşitlilik taşımakta ve görünüşleri itibariyle farklılık göstermektedir. Morchella türleri süngere benzer bir şekilde şapka ve kalın bir sapa sahiptir. Kuzugöbeği mantarı dünyada, özellikle kuzey yarımkürede karlı kış sezonu geçiren ılıman ve boreal ormanları olan tüm ülkelerde yetişmektedir (Arora 1986). Ayrıca, bazı Akdeniz veya subtropikal bölgelerdeki gibi kıyı Kaliforniya (Arora 1986; Kuo 2005), Meksika, Guatemala Yaylaları (Guzmán-Dávalos ve Rodríguez-Alcantar 1993; Guzmán ve Tapia 1998) ve Orta Doğu'da (Goldway vd. 2000) da görülmektedir. Güney Yarımkürede bulunan birçok kuzugöbeği mantarı türünün muhtemelen Kuzey Yarımküre'den yayıldığı, ancak bölgede birkaç endemik türün de olduğu tespit edilmiştir (Barnes ve Wilson 1998).

Tablo 1: Kuzugöbeği mantarlarından M. esculenta'nın protein, yağ ve karbonhidrat içerikleri (Crisan ve Sands 1978)

\begin{tabular}{|c|c|c|c|}
\hline Latince ismi & Protein* & Yağ* & Karbonhidrat* \\
\hline Morchella esculenta & 29.7 & 3.6 & 51.3 \\
\hline *Değerler yaş madde ağırlığı baz alınarak verilmiştir $(\mathrm{g} / 100 \mathrm{~g})$
\end{tabular}

Kuzugöbeği mantarının fruktifikasyonunun başladığı zaman, genel olarak kışın karların eriyip toprağın 1sınmaya başladığı ve havanın nemli olduğu zamanlardır (Greene vd. 2010; Pilz vd. 2004; Y1ldız 2011). Fruktifikasyonun gerçekleşebilmesi için toprak neminin \%20'nin üzerinde, sıcaklığın ise 10-20 ${ }^{\circ} \mathrm{C}$ arasında olması gerekmektedir (Hervey vd. 1978). Ayrıca, nisbi nem \%57-77 arasında, pH nötr ve Ca, K, P'un var olduğu alanlarda mantar fruktifikasyonu görülebilmektedir (Kaul vd. 1981). 
Mantarın alanda bulunma süresi herhangi bir yerdeki mevsim, yağış, nem, topografya ve mantar türüne bağlı olarak birkaç haftadan birkaç aya kadar sürebilmektedir (Taşkın ve Büyükalaca 2012). Sıcaklık ve nem, mantarların gelişmeleri için gereken koşullardır. Rakım ve bakı da kuzugöbeği mantarı için önemli olup, önce düşük yükseklikte ve erken ısınan güneye bakan yamaçlarda, daha sonra yüksek sırtlarda ve kuzeye bakan yamaçlarda mantar oluşmaktadır (Pilz vd. 2007).

Çok geniş bir alanda yayılış gösteren kuzugöbeği mantarının Index Fungorum çevrimiçi veri tabanında dünya genelinde 350 tür ve alttürü listelenmektedir (URL-2 2020). Bu mantar türleri; makroskopik olarak (çıplak gözle) veya mikroskobik olarak görülebilen şekil veya diğer özelliklerinden (örneğin renk veya doku) ayırt edilmişlerdir. Bu mantar türlerinin fiziksel olarak ayırt edilirken özellikle tepe, çukur ve sap renkleri, mantarın baş kısmının sapa tutturulması, baş ve sap dokusu gibi özelliklerden yararlanılmıştır. Kuzugöbeği türleri ayırt edilirken karşılaşılan en büyük problem mantarın tek bir türünün bile aşırı polimorfik (çok çeşitli formlar sergilemesi) olmasıdır. Bu polimorfizm kuşkusuz genetik bir bileşene sahiptir, ancak rutubet ve güneş 1 şı̆̆1 gibi çevresel koşullar kuzugöbeği mantarının büyümesini, gelişimini, biçimini, boyutunu ve rengini de etkileyebilir. Örneğin, Jung vd. (1993), farklı büyüklükteki sarı, taba ve gri mantarların aslında aynı soydan gelen tek bir polimorfik tür olan sarı kuzugöbeği mantarı olduğunu iddia etmişlerdir. Jacobs (1982) 10 farklı mantarın ultraviyole ışınlara tepki olarak renk değiştirebildiğini, sıcaklığın ve nem koşullarının olumlu olması halinde mantar büyüklüklerinin de farklı olabileceğini belirtmiştir. Thompson ve Colgan (1994), kuzugöbeği mantar türlerini belirlerken, mantarı bulduğu yerde büyüyen ağaç türleri ile önemli oranda ilişkili olduğu ve belki de gıda kaynaklarının da morfolojiyi belirlemede rol oynadığını belirtmiştir.

Kuzugöbeği mantarları genelde 5-15 cm boyunda ve kremden koyu kahverengiye kadar değişen renkleri ile kolayca tanınabilecek yapıdadır. Sporları askus adı verilen bir kese içinde bulunur ve bu keseden atılan sporlar uygun çimlenme koşullarıyla mantarı meydana getirirler (Solak vd. 2002).

Genellikle Morchella türleri 3 farklı grup altında incelenmektedir. Bunlar; Morchella rufobrunnea grubu (beyaz kuzugöbekleri), Morchella esculenta grubu (sarı kuzugöbekleri) ve geç farklılaşan Morchella elata grubu (siyah kuzugöbekleri) dur (Bozok vd. 2020). Yapılan çalışmalar kapsamında belirlenen kuzugöbeği mantarlarının büyük kısmını, Elata (siyah) kuzugöbeği mantar grubunun oluşturduğu belirtilmiştir (Keskinkılıç ve Taşkın 2019).

Bu güne kadar Türkiye’de 21 adet kuzugöbeği mantarı türü, moleküler yöntemlerin de kullanılması desteğiyle belirlenmiștir (Taşkın vd. 2010, 2012; Isiloğlu vd. 2010). Fakat Türkiye 'de Morchella cinsi üyelerinin yetiștiği birçok alan olduğu tahmin edilmekte ve bu kapsamda Türkiye’nin kuzugöbeği mantarı çeşitliliğinin 21 adetle sınırlı kalmadığı düşünülmektedir (Bozok vd. 2020).

\subsection{Yangın ve Kuzugöbeği Mantarı İlişkisi}

Kuzugöbeği mantarları, çok çeşitli orman ekosistemleri ve habitatlarında bulunur. Yüksek genetik ve morfolojik çeşitliliğe sahip olup, birçok farklı türü doğada bulunmaktadır. Ancak, türler arasındaki ayrımı yapmak oldukça zordur. Bazı kuzugöbeği mantar türler başka canlılar ile birlikte karşılıklı yarar ilişkisine dayalı bir yaşam sürdüren mutualist mantarlar olup (Buscot ve Roux 1987), bazıları ise bozulmuş toprakta ve orman yangınlarından sonra alana gelen, genelde ölmüş veya çürümekte olan bitki ve hayvanların içerdiği organik bileşikleri kullanan saprofit mantarlardır (Kaul vd. 1981; Carpenter ve Derrickson 1987). Bu mantarlar genellikle soğuk-1lıman alanlarda iğne yapraklı ormanlarda ve yangın sonrasında ilkbahar veya yaz aylarında bol miktarda gözlenmiștir (Apfelbaum ve Sams 1984; Carpenter ve Derrickson 1987; Dickman ve Cook 1989; Duchesne ve Weber 1993). Yapılan çalışmalar, genellikle yangın görmüş, ölü ağaçların bol olduğu ve toprak bozulmalarının olduğu, tahribata uğramış ormanlarda da kuzugöbeği fruktifikasyonunun gerçekleştiğini göstermektedir. Mantarın oluşmasını sağlayan bu tür tahribatlar, türe göre de farklılık arz etmektedir. Örneğin, araştırmacılar ve mantar toplayıcıların sıkça yaptığı gözlemler; yanmış ve yanmamış sahalardaki kuzugöbeği mantar türlerinin birbirinden ayırt edildiğini göstermektedir (McFarlane vd. 2005; McLain vd. 2005; Pilz vd. 2004). Araştırmalar bazı mantar türlerinin yalnızca orman yangınlarından bir ya da iki yıl sonra ortaya çıktıklarını, buna karşılık diğer türlerin yanmayan bölgelerde her yıl meydana geldiğini göstermektedir. Bu mantar türleri kendi içerisinde "yanmış" ve "yanmamış" mantar türleri olarak sınıflandırılmıştır. "Yanmamış" türler dediğimiz mantarlar da genellikle toprak kayması, toprak sıkıșması, ağaç ölümleri ve ormancılık faaliyetleri gibi alanda meydana gelen bozukluklar sonrasında oluşmaktadır. Kuzugöbeği mantarının bazı türleri, çoğunlukla yangından sonra birkaç yıl boyunca bol miktarda çıkabilmektedir. Bu nedenle bazı bölgelerde yangın mantarı olarak da bilinmektedir. Pilz vd. (2004), Morchella cinsine ait bazı türlerin sadece yanmış alanlarda yetiştiğini gözlemlemişlerdir. Ülkemizde orman yangınlarından sonra görülen kuzugöbeği mantarı türlerinden bazıları M. importuna, M. eximia, M. dunensis'dir (Taşkın vd. 2010, 2012; Loizides 2017).

Orman yangınları sonrasında kuzugöbeği mantarının alanda bol miktarda görülme sebepleri araştırıldığında, yangın ile birlikte meşcere yapısında ve ekosistemin toprak dinamiklerindeki ani değişimler sonrasında, mantarların kullanabileceği bol miktarda besin elementine sahip ve rekabetin az olduğu alanlar ortaya çıkmaktadır (Penttilä ve Kotiranta 1996; Pilz 2007). Böylece yangın görmüş alanlarda bol miktarda mantar türü ve sayısı görülmektedir. Bunun sebebi; yangınla birlikte ortaya çıkan 1sı, mantarların spor ve skleroitlerini uyarmakta ve çimlenmeyi sağlamaktadır. Yangın sonrası ortaya çıkan 1sı toprakta mantar ile rekabet halinde bulunan mikroorganizmaların çoğunu öldürmektedir (Bilgili vd. 2019). 
Yangın, toprağın ısınması ile mantar oluşumunu engelleyen maddelerin konsantrasyonunu azaltabilmekte (Duchesne ve Weber 1993) ve askokarp oluşumunu engelleyecek ölü örtüyü ortadan kaldırmaktadır (Apfelbaum ve Sams 1984). Yapılan çalışmalarla orman yangını görmüş sahalarda yangını takip eden 1-2 yıllık süre zarfında mantar miktarında hızlı bir artış ve ardından bir azalış yaşandığı ortaya konulmuştur (Du vd. 2015; Masaphy ve Zabarı 2013). Winder ve Keefer (2008), yangından sonra ortalama kuzugöbeği mantar çıkışının yaklaşık dönümde 6500 adet olduğunu bulmuştur. Diğer bir çalışmada, iğne yapraklı ormanda yangın sonrası kuzu göbeği mantar bolluğunun yangını takip eden ilk yılda hektarda yaklaşık 1700 adet olduğu tespit edilmiştir (Larson vd. 2016). Bu ve benzeri çalışmalar doğrultusunda yangın bölgelerinden toplanan mantarların belli tür gruplarında bulunması kuzugöbeği mantarının yangınla olan ilişkisini desteklemektedir (Taşkın 2011). Bu çalışmada, orman yangını sonrası fiziksel ve kimyasal toprak özelliklerinde meydana gelen değişimlerin, kuzugöbeği mantarının oluşumuna olan etkilerinin belirlenmesi amaçlanmaktadır.

\section{Materyal ve Yöntem}

\section{1. Çalışma Alanı}

Çalışma alanı olarak; Giresun Orman Bölge Müdürlüğü, Şebinkarahisar Orman İşletme Müdürlüğü, Alucra Orman İşletme Şefliği sınırları içerisinde bulunan, Boyluca ve İğdecik mevkii olarak seçilmiştir (Şekil 1). Temmuz 2015'de Boyluca Yaylasında örtü yangını görmüş alan, saf sarıçam meşceresi iken, Eylül 2016'da yine örtü yangını görmüş İğdecik Yaylasındaki alan üç farklı meşcereden oluşmaktadır. Aşağıdaki tabloda, meşcerelerin özellikleri ayrıntılı şekilde ifade edilmiştir (Tablo 2).

Tablo 2: Çalışma alanlarının meşcere özellikleri

\begin{tabular}{|c|c|c|c|c|c|c|c|c|}
\hline $\begin{array}{c}\text { Çalışma } \\
\text { Alanı }\end{array}$ & $\begin{array}{c}\text { Meşcere } \\
\text { Tipi }\end{array}$ & $\begin{array}{c}\text { Ăgaç } \\
\text { Türü }\end{array}$ & $\begin{array}{c}\text { Gelişim } \\
\text { Çağı (cm) }\end{array}$ & $\begin{array}{c}\text { Kapalılık } \\
(\mathbf{\%})\end{array}$ & $\begin{array}{c}\text { Alan } \\
(\mathbf{h a})\end{array}$ & Bakı & $\begin{array}{c}\text { Rakım } \\
(\mathbf{m})\end{array}$ & $\begin{array}{c}\text { Eğim } \\
(\mathbf{\%})\end{array}$ \\
\hline $\begin{array}{c}\text { Boyluca } \\
\text { Yaylas1 }\end{array}$ & Çsbc3 & Sarıçam & $8-35,9$ & $>70$ & 2 & Güney- Batı & 2100 & 45 \\
\hline $\begin{array}{c}\text { Ĭğdecik } \\
\text { Yaylas1 }\end{array}$ & BÇsKv & $\begin{array}{c}\text { Sarıçam- } \\
\text { Kavak }\end{array}$ & - & $<10$ & 1,5 & Güney-Batı & 2350 & 40 \\
\hline $\begin{array}{c}\text { Ĭğdecik } \\
\text { Yaylas1 }\end{array}$ & Kvab2 & Kavak & $0-19,9$ & $40-70$ & 2,5 & Güney-Batı & 2320 & 40 \\
\hline $\begin{array}{c}\text { Ĭğdecik } \\
\text { Yaylas1 }\end{array}$ & ÇsKvbc1 & $\begin{array}{c}\text { Sarıçam- } \\
\text { Kavak }\end{array}$ & $8-35,9$ & $10-40$ & 3,5 & Güney-Batı & 2370 & 40 \\
\hline
\end{tabular}

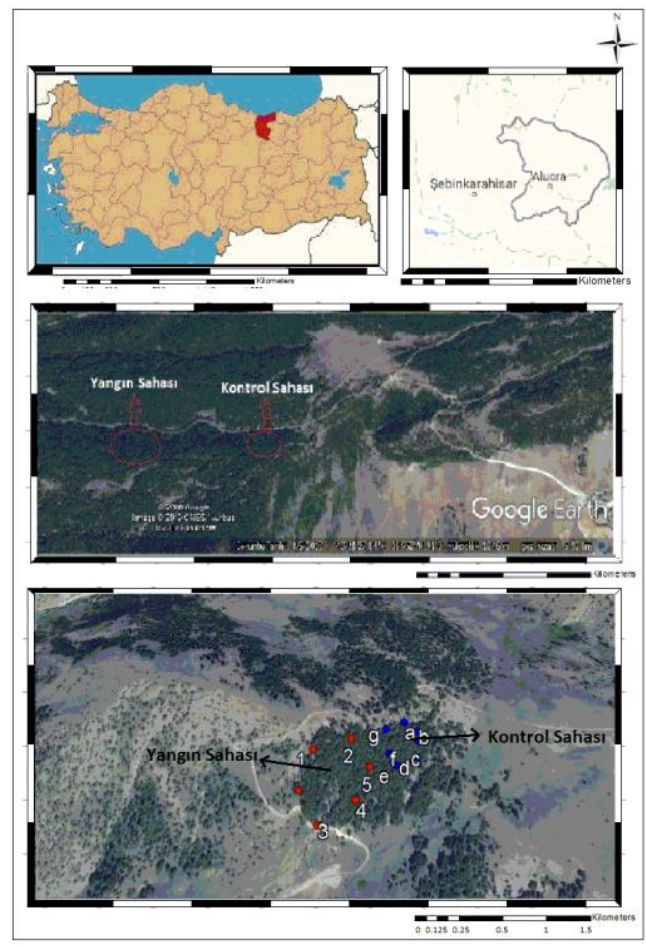

Şekil 1: Çalışma yapılan meşcereler 
Uzun yılların değerlendirilmesiyle oluşturulan meteorolojik verilere göre, çalışma alanının yıllık ortalama sıcaklık $8^{\circ} \mathrm{C}$, yıllık ortalama yağış miktarı 476 mm iken, yıllık ortalama nispi nem oranı \%67'dir (URL-3 2020).

Çalışmada, yangın görmüş ve kuzugöbeği mantarının görüldüğü noktalardan 30 adet, yangın görmüş ve kuzugöbeği mantarının görüldüğü nokta merkez kabul ederek oluşturulan 1 metre çapındaki çember içerisinden 30 adet, yangın görmüş ve kuzugöbeği mantarı görülmeyen noktalardan 30 adet ve alanın yakınında aynı ekolojik özelliğe sahip yanmamış alanlardan seçilen kontrol noktalarından 30 adet olmak üzere birinci yılda 150, ikinci yılda 90 adet olmak üzere toplam 240 toprak örneği 0-10 cm derinliğinden, ortalama yarım kilo ağırlı̆̆ında torba örneği şeklinde alınmıștır (Tablo $3)$.

Tablo 3: Çalışma kapsamında alınan toprak örnekleri sayıları

\begin{tabular}{|c|c|c|c|c|c|c|}
\hline \multicolumn{5}{|c|}{ Boyluca Yaylası Örnekleri } & \multicolumn{3}{c|}{ Ĭgdecik Yaylası Örnekleri } \\
\hline Yangın & Mantar & $\begin{array}{c}1 . \text { Y1l } \\
\text { (Adet) }\end{array}$ & $\begin{array}{c}2 . \text { Y1l } \\
\text { (Adet) }\end{array}$ & Yangın & Mantar & Adet \\
\hline$+*$ & + & 30 (Dip) & $-* *$ & + & + & - \\
\hline+ & + & $\begin{array}{c}30 \\
\text { Cevre) }\end{array}$ & - & + & + & - \\
\hline+ & - & 30 & 30 & + & - & 30 \\
\hline- & - & 30 & 30 & - & - & 30 \\
\hline \multicolumn{7}{|c|}{ TOPLAM } \\
\hline
\end{tabular}

Boyluca Yaylasındaki toprak örnekleri, kuzugöbeği mantarının çoğalmasının (proliferasyonunun) görülmeye başladığı zaman olan yangını takip eden ilkbaharda, karların erimeye başladığı, toprağın ısındığı ve havanın hala nemli olduğu zaman olan 2016 yılı Mayıs ayının ikinci haftasında alınmıştır. İkinci yıl toprak örneklerinin alımı, aynı tarihlerde yapılmıştır. İğdecik Yaylasındaki toprak örnekleri 2017 yılı Mayıs aynının ikinci haftasında alınmış olup alanda mantar görülmediğinden ikinci yıl örnek alımı yapılmamıştır. Orman yangınlarının, toprağın fiziksel ve kimyasal özelliklerinde birçok değişikliğe sebep olduğu bilinmektedir. Ayrıca, mantarların çoğalmasında toprak ve iklim şartları oldukça belirleyicidir. Bu bağlamda, çoğalmada etkili olan; toprağın toplam organik maddesi ve toprak pH'sı analizleri yapılarak yangının toprağın kimyasal özellikleri üzerine etkileri ortaya konulmuştur. Topraktaki toplam organik madde analizi, organik karbon Walkley-Black sslak yakma metodu ile tayin edilmiştir. Organik karbondan gidilerek toprağın organik maddesi hesaplanmıştır (Kantarcı 2000). Toprak reaksiyonu (pH) analizi, cam elektrot metodu ile ölçülmüştür. Aktüel asitlik için topraklar saf su ile 1slatılıp bir gece bekletildikten sonra ölçülerek bulunmuştur (Gülçur 1974).

Elde edilen $\mathrm{pH}$ ve organik madde değerleri ile örnek alanlar arasında bir fark olup olmadığını incelemek için istatistiki analiz yapılmıştır. Her bir örnek alandan alınan toprak örneği 30 adettir. Dolayısıyla, bu değerleri analiz etmek için en uygun test tek yönlü ANOVA testidir. Testin uygulanması için IBM SPSS Statistics $19^{\mathrm{TM}}$ paket programı (2010) kullanılmıştır

\section{Bulgular}

Topraktaki toplam organik madde tayini için yapılan organik karbon Walkley-Black sslak yakma metodu ve toprak reaksiyonu tayini için kullanılan cam elektrot metodu sonuçları yangın ve mantar durumlarına göre sınıflandırılıp ortalamaları alınmıştır. Boyluca Yaylası (Tablo 4) ve İğdecik Yaylası (Tablo 5) toprakları için toprak asitliği ve organik madde analizlerin ortalamaları aşağıdaki tablolarda verilmiştir.

Tablo 4: Boyluca Yaylası 1. ve 2. yıl toprak örneklerinin ortalama pH ve organik madde analiz sonuçları

\begin{tabular}{|c|c|c|c|c|c|}
\hline \multicolumn{2}{|c|}{$\begin{array}{c}\text { Yangın Görmüss ve Mantar } \\
\text { Görülme Durumu }\end{array}$} & \multicolumn{2}{c|}{1. Y1l } & \multicolumn{2}{c|}{ 2. Y1l } \\
\hline Yangın & Mantar & $\mathrm{pH}$ & $\begin{array}{c}\% \text { Organik } \\
\text { Madde }\end{array}$ & $\mathrm{pH}$ & $\begin{array}{c}\% \text { Organik } \\
\text { Madde }\end{array}$ \\
\hline+ & + (Dip) & 6.78 & 7.08 & $*$ & $*$ \\
\hline+ & + (Çevre) & 6.65 & 7.40 & $*$ & $*$ \\
\hline+ & - & 6.50 & 5.82 & 6.28 & 6.30 \\
\hline- & - & 5.98 & 5.65 & 5.99 & 6.07 \\
\hline 2. yll alanda mantar görülmediğinden mantarl toprak örneği yoktur.
\end{tabular}


Tablo 5: İğdecik Yaylası toprak örneklerinin ortalama $\mathrm{pH}$ ve organik madde analiz sonuçları

\begin{tabular}{|c|c|c|c|}
\hline Yangın & Mantar & $\mathrm{pH}$ & $\begin{array}{c}\text { \% Organik } \\
\text { Madde }\end{array}$ \\
\hline+ & - & 6.09 & 8.17 \\
\hline- & - & 6.30 & 5.74 \\
\hline
\end{tabular}

Organik madde için yapılan istatistik analiz sonucu önemlilik düzeyi p<0.05 (Tablo 6) olduğundan, örnek alanların organik madde değeri açısından farklılık gösterdiği sonucuna varılmıştır. Boyluca Yaylasından alınan toprak örneklerinde organik madde analizi değerleri ile yapılan istatistik analiz sonuçlarına göre, yangın görmüş mantarlı alanda çevre ve dip toprak örnekleri arasında anlamlı bir fark olmadığı, diğer örnekler arasında anlamlı fark olduğu görülmüştür. Aynı işlem, İğdecik Yaylası toprak örneklerinde de geçerli olup yangın görmüş alanlar ile yangın görmemiş alanlar arasında anlamlı bir fark gözlemlenmiştir.

Tablo 6: Ĭğdecik Yaylası toprak örneklerinin organik madde ANOVA analiz sonuçları

\begin{tabular}{|l|c|c|c|c|c|}
\hline & Kareler Toplamı & $\begin{array}{c}\text { Serbestlik } \\
\text { derecesi }\end{array}$ & Kareler Ortalaması & F & $\begin{array}{c}\text { Önemlilik } \\
\text { Düzeyi }\end{array}$ \\
\hline Gruplar Arası & 177.612 & 7 & 25.373 & 16.150 & .000 \\
\hline Gruplar İçi & 364.495 & 232 & 1.571 & & \\
\hline Toplam & 542.108 & 239 & & & \\
\hline
\end{tabular}

Toprak reaksiyonu için yapılan analiz sonucu önemlilik düzeyi p<0.05 (Tablo 7) olduğundan, örnek alanlar pH değeri açısından farklılık gösterir. Boyluca Yaylasından alınan toprak örneklerinde yapılan $\mathrm{pH}$ analiz sonuçlarına göre yangın görmüş mantarlı sahalarda dip ve çevre arasında istatistiksel olarak anlamlı bir fark olmadığı, diğer alanlar arasında ise anlamlı fark olduğu analiz edilmiştir. İğdecik Yaylası toprak örnekleri için bakıldığında ise yangın görmüş alanlar ile yangın görmemiş alanlar arasında anlamlı bir fark bulunmamaktadır.

Tablo 7: Ĭğdecik Yaylası toprak örneklerinin ortalama pH ANOVA analiz sonuçları

\begin{tabular}{|l|c|c|c|c|c|}
\hline & Kareler Toplamı & $\begin{array}{c}\text { Serbestlik } \\
\text { derecesi }\end{array}$ & Kareler Ortalaması & F & $\begin{array}{c}\text { Önemlilik } \\
\text { Düzeyi }\end{array}$ \\
\hline Gruplar Arası & 19.831 & 7 & 2.833 & 31.746 & .000 \\
\hline Gruplar İçi & 20.704 & 232 & .089 & & \\
\hline Toplam & 40.535 & 239 & & & \\
\hline
\end{tabular}

\section{Sonuç ve Tartışma}

Araştırmalar gösteriyor ki; orman yangıları ile birlikte toprak üstünde bulunan ölü ve diri örtünün yanması sonucu Ca, $\mathrm{Mg}, \mathrm{K}, \mathrm{Na}$ vb. alkaliler toprağa geçerek topraktaki organik maddeyi artırmaktadır (Kaul vd. 1981). Bunun yanında değişebilir hidrojen katyonlarının azalması sonucu toprak asitliğinde de azalma meydana gelmekte ve böylece toprak pH'sı bir miktar artmaktadır (Çepel 1975). Analiz sonuçlarına baktığımızda, yanmamış sahadan alınan toprak örneklerinin $\mathrm{pH}$ ve organik madde değerlerinin ortalamaları sırasıyla 5.98 ve 5.65 iken, yangın görmüş mantarlı sahalardan alınan toprak örneklerinin $\mathrm{pH}$ ortalaması 6.71, organik madde ortalamaları ise 7.25 olarak artış göstermiştir.

Yapılan analizler doğrultusunda, mantarın çoğalması için gerekli pH yangın sonrasında sağlanmaktadır (Tablo 3). Ancak gerekli pH sağlansa dahi organik madde açısından zengin olmayan alanlarda mantar çoğalması görülmemektedir. Boyluca Yaylasında mantar görülen yerlerdeki organik madde ve $\mathrm{pH}$ değerlerine bakıldığında, her ikisinin de istenilen düzeyde olduğu görülmektedir. İğdecik Yaylasında ise mantar görülmemesinin, pH seviyesinin istenilen düzeye çıkmamasından kaynaklandığı söylenebilir (Tablo 4). En yüksek organik madde oranı İğdecik Yaylasında görülmesine rağmen, pH seviyesinin düşük olması mantar oluşumuna engel teşkil etmektedir. Rakımın yükselmesine bağlı sıcaklık düşüşü de bu alanda mantar görülmemesinin diğer sebebi olarak düşünülmektedir.

Boyluca Yaylasında yangın görmüş, mantar bulunmayan alandan alınan toprak örneklerinin $\mathrm{pH}$ ve organik madde ortalamalarına bakıldığında; $\mathrm{pH}$ 'nın nötre yakın fakat organik maddenin düşük olması bir kez daha hem pH'nın hem de organik maddenin aynı anda yeterli düzeyde olması gerektiğini göstermiştir. Mantar görülen alanlarda, mantarın dip kısmından ve çevresinden alınan toprak örneklerinde hem $\mathrm{pH}$ hem de organik madde içerikleri arasında istatistiksel olarak anlamlı bir fark görülmemiştir.

Yangın sonrası mantar görülen Boyluca Yaylası Mayıs ayı sıcaklık ortalaması $10^{\circ} \mathrm{C}$ iken, mantar görülmeyen İğdecik Yaylası Mayıs ayı sıcaklık ortalamasının $8.5^{\circ} \mathrm{C}$ olduğu görülmektedir. Hervey vd. (1978)'nin yapmış olduğu çalışmada, kuzugöbeği mantarının $10^{\circ} \mathrm{C}$ ve üzerinde görüldüğü belirtilmekte olup, bu sonuç yapılan çalışmayı desteklemektedir. 
Orman yangınları sonucunda meşcere kapalılığı kırılır, ölü ve diri örtü yanar. Bununla birlikte, organik madde ayrışır. Bu durum sayesinde, toprak bitki besin maddesi ve $\mathrm{pH}$ açısından zengin bir hal alır. Toprak dinamiklerindeki bu değişimler, bitki beslenmesi açısından genelde olumlu görülen değişimlerdir (Eron ve Gürbüzer 1988; Neyișçi 1986; Masaphy vd. 2008; Tufekcioglu vd. 2010; Alcañiz vd. 2018; Úbeda vd. 2018).

Çalışmada yangın görmüş alanlarda ortalama $\mathrm{pH}$ değerinin nötre yakın olması ve organik madde miktarının artmasıyla birlikte, kuzugöbeği mantarı furiktifikasyonlarında artış gözlemlenmiştir. Benzer sonuçlar, Kaul vd. (1981) tarafından, nisbi nem \%57-77 arasında, pH nötr ve Ca, K, P'un yeterli seviyelerde olduğu alanlarda, kuzugöbeği mantarı fruktifikasyonunun görülebildiği çalışmada ortaya konulmuştur. Yine aynı şsekilde, Winder (2006) yapmış olduğu çalışmada da, kuzugöbeği mantarının en uygun $\mathrm{pH}$ değerinin 7.0 olduğu belirtilmiştir.

Yangından sonra farklı ormancılık uygulamalarının (kesim ve bölmeden çıkarma işlemleri) da kuzugöbeği mantarı yoğunluğunu etkilediği yapılan çalışmalarda gözlemlenmiştir (Masaphy ve Zabari 2013). Söz konusu çalıșmada, müdahale edilmeyen yangın görmüş sahada $500 \mathrm{~m}^{2}$ de 34 adet mantar gözlemlenirken, işlem gören (dozer ile alan temizleme) yangın görmüş alanda 170 adet mantar gözlemlenmiştir. Yaptığımız bu çalışmada yangından sonra alanda herhangi bir ormancılık faaliyeti yapılmadığından dolayı, alan müdahalesinin kuzugöbeği mantarı üzerine etkisi gözlemlenememiştir. Kısaca söylenebilir ki mantarın çoğalabilmesi için sadece pH'nın değil, organik maddenin de yeterli düzeyde olması gerektiği çalışma ile ortaya konulmuştur. Kuzugöbeği mantarının bazı türlerinin tahribata uğrayan veya yangın geçiren alanlarda daha fazla görüldüğü yapılan diğer çalışmalarda da belirtilmiştir (Pilz vd. 2004; Stamets 2000; Weber 1988; Thompson ve Colgan 1994; Keefer 2005).

Ülkemizde ekonomik değeri yüksek olan Morchella türlerinin, odun dışı orman ürünü olarak daha fazla yayılış gösterdiği alanlarda envanterinin yapılması gerekmektedir. Özellikle orman yangını olmuş alanlar için yangını takip eden yıllarda alandaki mantarların OGM'nin 297 sayılı tebliğinin 15. Maddesine göre yıllık üretim programına alınmayan odun dışı orman ürünlerinin üretim ve toplanma usullerine göre üretime açılması sağlanmalıdır.

Bazı kuzugöbeği mantar türlerinin yanan alanlarda daha çok görüldüğü göz önüne alındığında, bu tür alanlar planlı ve kontrollü bir üretim yaklaşımı uygulanmak şartıyla orman köylüleri için önemli bir gelir sağlama potansiyeli oluşturabilecektir. Bu bağlamda köylüler tarafından kuzugöbeği üretimi yapılan ve özellikle yapısı itibariyle düşük şiddetli örtü yangınından zarar görmeyecek yaşlı meşcerelerde, OGM'nin kontrolünde yapılacak amaçlı yakma çalışmalarıyla ilgili alanlardaki mantar üretiminin desteklenebilmesi ve benzeri verim artırıcı çalışmaları içeren planlamalar da düşünülmelidir. Bu konuda kuzugöbeği mantarı mevcut ve potansiyel üretim miktarları, potansiyel alanlar, yakma zamanı ve yöntemleri ile ilgili iş ve işlemlerin ele alındığı diğer odun dışı orman ürünleri için hazırlanan eylem planlarına benzer şekilde bir plan hazırlığı üzerinde çalışılmalıdır.

Bu konuda mevcut üretim ve potansiyel üretim miktarları, uygun alanlar, yakma zamanı ve yöntemleri ile ilgili iş ve işlemlerin ele alındığı bir plan üzerinde çalışılmalıdır. Burada en önemli husus, yakma zamanının ve yangın şiddetinin arzu edilen $\mathrm{pH}$ ve organik madde miktarını elde edecek şekilde planlanmasıdır. Bunu sağlamak için farklı hava halleri ve yanıcı madde şartlarında yapılacak amaçlı yakma araştırmalarıyla uygun $\mathrm{pH}$ ve organik madde düzeylerine hangi şartlarda ulaşıldığının ortaya konulması gerekmektedir. Bu çalışma altlığında aynı sınırlar içerisinde arzu edilen şartları elde etmek üzere amaçlı yakmaların planlanması mümkün olabilir. Bu çalışmalar ancak OGM tarafından gerekli izin, kontrol ve tedbirlerin alınmasıyla, yangınlar konusunda yetkin kişilerce ve uygun alanlarda yapılabilir. Yapılacak amaçlı yakmanın maliyeti düşük olsa bile, oluşturacağı etkinin yanı sıra rekoltede yapacağı artışla birlikte, bu yöntemin uygulamada kullanılabilirliği etraflıca tartışılmalıdır. Bu uygulama ile orman alanlarında her hangi bir zarar oluşturmadan, birtakım toprak özelliklerinin değiştirilmesi suretiyle mantar üretiminin önemli oranda artırılması mümkün olabilir.

\section{Teşekkür}

Bu çalışmaya (2016.F10.02.16) maddi destek sağlayan Artvin Çoruh Üniversitesi, Bilimsel Araştırma Projesi Koordinatörlüğüne teşekkür ederiz.

\section{Kaynaklar}

Alcañiz M., Outeiro L., Francos M., Úbeda X., (2018), Effects of prescribed fires on soil properties: A review, Science of the Total Environment, 613-614, 944-957.

Anguiano A.C.R., Santoyo S., Reglero G., Rivas C.S., (2007), Radical scavenging activities, endogenous oxidative enzymes and total phenols in edible mushrooms commonly consumed in Europe, J Sci Food Agric, 87, 2272-2278.

Apfelbaum S.I., Sams C.E., (1984), Ecology and control of reed canary grass (Phalaris arundinacea L.), Natural Areas Journal, 7(2), 69-74.

Arora D., (1986), Mushrooms demystified: a comprehensive guide to the fleshy fungi. 2nd edition, Berkeley: Ten Speed Press, 959ss.

Barnes S., Wilson A., (1998), Cropping of the French black morel: a preliminary investigation. Australia: Rural Industries Research and Development Corp. 98/44. 14 ss.

Bilgili E., Usta Y., Coskuner K.A., Balcıoglu K., (2019), Amaçlı yakmaların mantar üretimi için saf çam ormanlarında kullanım potansiyeli, III. International Mediterranean Forest and Environment Symposium, Kahramanmaraș, ss. 202-205.

Bozok F., Keskinkılıç İ., Akata İ., Yarar M., Taşkın H., (2020), Moleküler Yöntemlerin Kullanımı İle Türkiye Morchella (Kuzugöbeği) Genetik Çeşitliliğine Katkılar, Mantar Dergisi, 11(2), 142-157. 
Buscot F., Roux J., (1987), Association between living roots and ascocarps of Morchella rotunda, Transactions of the British Mycological Society, 89(2), 249-252.

Carluccio A., (1995), A Passion for Mushrooms. Pavilion Books Limited, London, 192 ss.

Carpenter J.W., Derrickson S.R., (1987), Infectious and parasitic diseases of cranes: principles of treatment and prevention, Proceedings of the International Crane Workshop, International Crane Foundation, Baraboo, Wisconsin, ss. 539-553.

Crisan E.V., Sands A., (1978), Nutritional value (pp. 137-168). New York: Academic Press.

Çepel N., (1975), Orman Yangınlarının Mikroklima ve Toprak Özellikleri Üzerine Yaptığı Etkileri. İ. Ü. Or. Fak. Der. Seri B, 25(1), 71-93.

Dickman A., Cook S., (1989), Fire and fungus in a mountain hemlock forest, Canadian Journal of Botany, 67(7), 2005-2016.

Du X.H., Zhao Q., Yang Z.L., (2015), A review on research advances, issues, and perspectives of morels, Mycology, 6(2), 78-85.

Duchesne L.C., Weber M.G., (1993), High incidence of the edible morel Morchella conica in a Jack pine, Pinus banksiana, forest following prescribed burning, The Canadian Field Naturalist, 107(1), 114-116.

Duncan C., Pugh J., Pasco G., David N., Ross S., Samir A., (2002), Isolation of a galactomannan that enhances macrophage activation from the edible fungus Morchella esculenta, Journal of Agricultural And Food Chemistry, 50, 5683-5685.

Eron Z., Gürbüzer E., (1988), Marmaris 1979 yılı orman yangını ile toprak özelliklerinin değişimi ve kızılçam gençliğinin gelişimi arasındaki ilişkiler, Ormancılık Araştırma Enstitüsü, Teknik Bülten No: 195, Ankara, 50 ss.

Greene D.F., Macdonald S.E., Haeussler S., Domenicano S., Noel J., Jayen K., Bergeron Y., (2007), The reduction of organic-layer depth by wildfire in the North American boreal forest and its effect on tree recruitment by seed. Canadian Journal of Forest Research, 37(6), 1012-1023.

Greene D.F., Hesketh M., Pounden E., (2010), Emergence of morel (Morchella) and pixie cup (Geopyxis carbonaria) ascocarps in response to the intensity of forest floor combustion during a wildfire, Mycologia, 102(4), 766-773.

Guzmán-Dávalos L., Rodríguez-Alcantar O., (1993), Registro de Morchella guatemalensis (Fungi, Ascomycotina) para México. Bol. Inst. Bot. Univ. Guadalajara, 1, 471-475.

Guzmán G., Tapia F., (1998), The known morels in Mexico, a description of a new blushing species, Morchella rufobrunnea, and new data on M. Guatemalensis, Mycologia, 90(4), 705-714.

Gülçur F., (1974), Toprağın Fiziksel ve Kimyasal Analiz Metodları, Kutulmuş Matbaası, İ.Ü. Yayın No. 1970, Orman Fakültesi Yayın No. 201, İstanbul, 225 ss.

Goldway M., Amir R., Goldberg D., Hadar Y., Levanon D., (2000), Morchella conica exhibiting a long fruiting season, Mycological Research, 104(8), 1000-1004.

Hervey A., Bistis G., Leong I., (1978), Cultural studies of single ascospore isolates of Morchella esculenta, Mycologia, 70(6), 12691274.

Iqbal M., (1993), International trade in non-wood forest products: an overview. Working Paper Misc/93/11. Rome, Italy: Food and Agriculture Organization of the United Nations.

Isiloğlu M., Alli H., Spooner B.M., Solak M.H., (2010), Morchella anatolica (Ascomycota), a new species from southwestern Anatolia, Turkey, Mycologia, 102(2), 455-458.

Jacobs M.E., (1982), Beta alanine and tanning polymorphisms, Comp. Biochem. Physiol. B. Comp. Biochem. 72:173-178.

Jung S., Gessner R., Keudell K., Romano M., (1993), Systematics of Morchella esculenta complex using enzyme-linked immunosorbent assay, Mycologia, 85:677-684.

Kalyoncu F., Oskay M., Sağlam H., Erdoğan T. F., Tamer A.U., (2010), Antimicrobial and antioxidant activities of mycelia of 10 wild mushroom species, J Med Food, 13(2), 415-9.

Kantarcı M.D., (2000), Toprak ilmi, İ.Ü. Yayınları Yayın No:4621, Orman Fakültesi Yayınları, Yayın No: 462, İstanbul.

Kaul T.N., Khurana M.L., Kachroo J.L., Krishna A., Atal C.K., (1981), Mushroom science 11. In Procedings of the Elevent International Scientific Congress On the Cultuvation of Edible Fungi, Australia, ss. 789-797.

Keefer M.E., (2005), The ecology and economy of morels in British Columbia's East Kootenay. Victoria, BC: Royal Roads University. Mémoire de maitrise.

Keskinkılıç İ., Taşkın H., (2019), Moleküler Yöntemlerin Kullanımı İle Türkiye Morchella (Kuzugöbeği) Cinsi Genetik Çeşitliliğine Katkılar, Çukurova Üniversitesi, Fen ve Mühendislik Bilimleri Dergisi, 38(2), 121-129.

Kuo M., (2005), Morels. 1st ed. Ann Arbor, MI: University of Michigan Press. 230.

Larson A.J., Cansler C.A., Cowdery S.G., Hiebert S., Furniss T.J., Swanson M.E., Lutz J.A., (2016), Post-fire morel (Morchella) mushroom abundance, spatial structure, and harvest sustainability, Forest Ecology and Management, 377, 16-25

Liu W., Chen L., Cai Y., Zhang Q., Bian Y., (2018), Opposite polarity monospore genome de novo sequencing and comparative analysis reveal the possible heterothallic life cycle of Morchella importuna, International journal of molecular sciences, 19(9), 2525.

Loizides, M., (2017). Morels: the story so far. Field Mycology, 18(2), 42-53.

Masaphy S., Zabari L., Gander-Shagug G., (2008), Morchella conica Pers. proliferation in post-fire forests in northern Israel, Israel Journal of Plant Sciences, 56(4), 315-319.

Masaphy S., Zabari L., (2013), Observations on post-fire black morel ascocarp development in an Israeli burnt forest site and their preferred micro-sites, Fungal Ecology, 6(4), 316-318.

McFarlane E.M., Pilz D., Weber N.S., (2005), High-elevation gray morels and other Morchella species harvested as non-timber forest products in Idaho and Montana, Mycologist, 19(2), 62-68.

McLain R.J., McFarlane E.M., Alexander S.J., (2005), Commercial morel harvesters and buyers in western Montana: an exploratory study of the 2001 harvesting season. USDA Forest Service-General Technical Report PNW.

Miller S.L., Torres P., McClean T.M., (1994), Persistence of basidiospores and sclerotia of ectomycorrhizal fungi and Morchella in soil. Mycologia, 86:89-95.

Neyişçi T., (1986), Antalya bölgesi kızılçam orman alanlarında kontrollü yangınların toprak besin maddesi üzerine yaptığ etkiler ve bu etkiler ile kızılçam gençliğinin gelmesi ve gelişmesi arasındaki ilişkiler, Doktora Tezi, İstanbul Üniversitesi, Fen Bilimleri Enstitüsü, İstanbul. 
Nitha B., Janardhanan K.K., (2008), Aqueous-ethanolic extract of morel mushroom mycelium Morchella esculenta, protects cisplatin and gentamicin induced nephrotoxicity in mice, Food Chem Toxicol, 46, 3193-3199.

Penttilä R., Kotiranta H., (1996), Short-term effects of prescribed burning on wood-rotting fungi, Silva Fennica, 30(4), $399-419$.

Pilz D., Weber N.S., Carter M.C., Parks C.G., Molina R., (2004), Productivity and diversity of morel mushrooms in healthy, burned, and insect-damaged forests of northeastern Oregon, Forest Ecology and Management, 198(1), 367-386.

Pilz D., McLain R., Alexander S., Villarreal-Ruiz L., Berch S., Wurtz T.L., Smith J.E., (2007), Ecology and management of morels harvested from the forests of western North America. Gen. Tech. Rep. PNW-GTR-710. Portland, OR: US Department of Agriculture, Forest Service, Pacific Northwest Research Station. 161ss.

Solak M.H., Yılmaz E.F., Gücin F., Işıloğlu M., (2002), Macrofungi of Balıkesir Province from Turkey, Bio-Science Research Bulletin, 18(2), 137-149.

Stamets P.E., (2000), Techniques for the cultivation of the medicinal mushroom royal sun Agaricus-Agaricus blazei Murr.(Agaricomycetideae), International Journal of Medicinal Mushrooms, 2(2), 10.

Taşkın H., Büyükalaca S., Doğan H.H., Rehner S.A., O’Donnell K., (2010), A multigene molecular phylogenetic assessment of true morels (Morchella) in Turkey, Fungal Genetics and Biology, 47(8), 672-682.

Taşkın H., (2011), Türkiye florasında yetişen kuzu göbeği mantarlarının moleküler karakterizasyonu, Doktora Tezi, Çukurova Üniversitesi Fen Bilimleri Ensitüsü, Adana.

Taşkın H., Büyükalaca S., (2012), Kuzu göbeği (morchella) mantarı, Bahçe, 41(1), 25-36.

Taşkın H., Büyükalaca S., Hansen K., O’Donnell K., (2012), Multilocus phylogenetic analysis of true morels (Morchella) reveals high levels of endemics in Turkey relative to other regions of Europe, Mycologia, 104(2), 446-461.

Thompson I.D., Colgan P.W., (1994), Marten activity in uncut and logged boreal forests in Ontario, The Journal of wildlife management, 58(2), 280-288.

Tufekcioglu A., Kucuk M., Saglam B., Bilgili E., Altun L., (2010), Soil properties and root biomass responses to prescribed burning in young corsican pine (Pinus nigraArn.) stands, Journal of Environmental Biology, 31(3), 369-373.

Úbeda X., Pereira P., Badía D. (2018), Prescribed fires, Science of the Total Environment, 637-638, 385-388.

URL-1, (2019), https://www.ogm.gov.tr/ekutuphane/Sayfalar/Istatistikler.aspx?RootFolder=\%2Fekutuphane\%2FIstatistikler\%2F Ormanc\%C4\%B11\%C4\%B1k\%20\%C4\%B0statistikleri\&FolderCTID=0x012000301D182F8CB9FC49963274E712A2DC00\&Vi ew $=\{4 B 3 B 693 B-B 532-4 C 7 F-A 2 D 0-732 F 715 C 89 C C\}$ Ormancılık İstatistikleri 2019, [Erişim 27 Ekim 2020].

URL-2, (2020), http://www.indexfungorum.org/names/Names.asp?pg=1, [Erişim 02 Kasım 2020].

URL-3, (2020), https://mgm.gov.tr/veridegerlendirme/il-ve-ilceler-istatistik.aspx?k=A\&m=Giresun/Alucra, [Erişim 08 Kasım 2020].

Weber N.S., (1988), A morel hunter's comp+anion: a quide to the true and false morels of michigan. lansing, MI: Two Peninsula Press, ss. 209.

Winder R.S., (2006), Cultural studies of morchella elata, Mycological research, 110(5), 612-623.

Winder R.S., Keefer M.E., (2008), Ecology of the 2004 morel harvest in the Rocky Mountain Forest District of British Columbia, Botany, 86(10), 1152-1167.

Yıldız M.S., (2011), Tokat (Pazar) yöresinde yetişen makromantarlarl üzerinde taksonomik bir araştırma. Yüksek Lisans Tezi, Gaziosmanpaşa Üniversitesi, Tokat. 